expression during chicken embryogenesis: detection of an embryonic isoform. Dev Dyn. 2001;221:460-3.

5. Jones JA, Beck C, Barbour JR, Zavadzkas JA, Mukherjee R, Spinale FG, et al. Alterations in aortic cellular constituents during thoracic aortic aneurysm development: myofibroblast-mediated vascular remodeling. Am J Pathol. 2009;175: 1746-56.

6. Slomp J, Gittenberger-de Groot AC Glukhova MA, van Munsteren JC, Kockx MM Schwartz SM, et al. Differentiation, dedifferentiation, and apoptosis of smooth muscle cells during the development of the human ductus arteriosus. Arterioscler Thromb Vasc Biol. 1997 17:1003-9.

7. Grewal N, Gittenberger-de-Groot AC, DeRuiter MC, Klautz RJM, Poelmann RE, Duim SN, et al. Bicuspid aortic valve: phosphorylation of c-Kit and downstream targets are prognostic for future aortopathy. Eur J Card Thor Surg. August 26, 2014 [Epub ahead of print]

8. Cotrufo M, Della CA, De Santo LS, Quarto C, De Feo M, Romano G, et al. Different patterns of extracellular matrix protein expression in the convexity and the concavity of the dilated aorta with bicuspid aortic valve: preliminary results J Thorac Cardiovasc Surg. 2005;130:504-11.

9. Mohamed SA, Noack F, Schoellermann K, Karluss A, Radtke A, Schult-Badusche D, et al Elevation of matrix metalloproteinases in different areas of ascending aortic aneurysms in patients with bicuspid and tricuspid aortic valves ScientificWorldJournal. 2012:2012:806261.

10. Bökenkamp R, Raz V, Venema A, DeRuiter MC van Munsteren C, Olive M, et al. Differentia temporal and spatial progerin expression during closure of the ductus arteriosus in neonates. PLoS One. 2011;6:e23975.

11. Olive M, Harten I, Mitchell R, Beers JK, Djabali K, Cao K, et al. Cardiovascular pathology in Hutchinson-Gilford progeria: correlation with the vascular pathology of aging Arterioscler Thromb Vasc Biol. 2010;30:2301-9.

12. Ragnauth CD, Warren DT, Liu Y, McNair R, Tajsic T, Figg N, et al. Prelamin A acts to accelerate smooth muscle cell senescence and is a novel biomarker of human vascular aging Circulation. 2010;121:2200-10.

http://dx.doi.org/10.1016/ j.jtcvs.2014.09.008

\section{MINIMALLY INVASIVE FULL BIATRIAL COX MAZE IV: WE ARE GOING IN THE RIGHT DIRECTION}

To the Editor:

I read with great interest the article by Lawrance and colleagues, ${ }^{1}$ and I congratulate them on this very interesting and well-written article. They have shown that the Cox maze IV procedure, with its inherent variations, can be performed by means of a less invasive right anterolateral minithoracotomy with excellent outcome. My personal preference is for the classic standard "cut-andsew" Cox maze III procedure. Once the surgeon has acquired technical expertise, this procedure is both easy and safe to do. What is truly important is not the complexity of the procedure, but rather the aortic crossclamp time. This is the rub, and this is why alternative energy sources for atrial fibrillation surgery have mushroomed in recent years. Since 2002, this has been termed as Cox maze IV procedure. Damiano and his working group $^{2}$ have been pioneers in this technology. The idea proposed by Lawrance and colleagues ${ }^{1}$ looks promising. In addition to the minimally invasive surgery, they used the only 2 energy sources that have been proved to be successful achieving full transmural lesions in the atria, bipolar radiofrequency and cryolesion. This great effort by Lawrance and colleagues ${ }^{1}$ in this article highlights that the trend is now toward the idea conceived by $\operatorname{Cox}^{3} 11$ years ago. He stated that surgery for atrial fibrillation should meet the following conditions: (1) the procedure should preferably be epicardial by nature; (2) the energy source should be capable of penetrating epicardial fat and ablating all types of atrial fibrillation; (3) cardiopulmonary bypass must be avoided; (4) the procedure should be amenable to endoscopic or minimally invasive techniques; (5) it should be performed in less than 1 hour; and (6) hospital discharge should be possible on the first postoperative day. Although it is true that not all these objectives have been achieved, we must recognize that we are on the right track. Novel devices are being developed ${ }^{4,5}$; as yet, however, transmural lesions have not been safely produced on the beating heart by epicardial ablation. Unfortunately, cardiopulmonary bypass remains a crucial aspect to perform this kind of procedure. The most important point is that we are going on the right direction, each moment getting closer to the goal. I really congratulate Lawrance and colleagues $^{1}$ for this fine and great effort.

Ovidio A. Garcia-Villarreal, $M D$

Department of Cardiac Surgery

Hospital of Cardiology UMAE 34

Instituto Mexicano del Seguro Social Monterrey, Mexico

\section{References}

1. Lawrance CP, Henn MC, Miller J, Sinn LA, Schuessler RB, Maniar HS, et al. A minimally invasive Cox-Maze IV is as effective as sternotomy while decreasing major morbidity and hospital stay. J Thorac Cardiovasc Surg. June 6, 2014 [Epub ahead of print].

2. Damiano RJ Jr, Badhwar V, Acker MA, Veeragandham RS, Kress DC, Robertson JO, et al. The CURE-AF trial: a prospective, multicenter trial of irrigated radiofrequency ablation for the treatment of persistent atrial fibrillation during concomitant cardiac surgery. Heart Rhythm. 2014;11:39-45.

3. Cox JL. Atrial fibrillation II: rationale for surgical treatment. J Thorac Cardiovasc Surg. 2003;126: 1693-9.

4. Sakamoto S, Voeller RK, Melby SJ, Lall SC, Chang N, Schuessler RB, et al. Surgical ablation for atrial fibrillation: The efficacy of a novel bipolar pen device in the cardioplegically arrested and beating heart. J Thorac Cardiovasc Surg. 2008; 136:1295-301.

5. Watanabe Y, Weimar T, Kazui T, Lee U, Schuessler RB, Damiano RJ Jr. Epicardial ablation performance of a novel radiofrequency device on the beating heart in pigs. Ann Thorac Surg. 2014; 97:673-8.

http://dx.doi.org/10.1016/ j.jtcvs.2014.07.017

\section{RUPTURE OF EXPANDED POLYTETRAFLUOROETHY- LENE NEOCHORDAE USED FOR MITRAL VALVE REPAIR: DOES SIZE MATTER? \\ To the Editor:}

In a report published in another journal in 2007, ${ }^{1}$ we reported 2 cases of rupture of synthetic chordae tendineae (expanded polytetrafluoroethylene [ePTFE]). We also analyzed the possible causes of what was then considered an extremely rare finding, which had first been reported by Buttany and 
colleagues. ${ }^{2}$ In that report, we hypothesized that, among others, inappropriate direct manipulation of the ePTFE by surgical instruments could be a causative factor. Subsequently, other groups $^{3-6}$ have reported such occurrences, which have become less rare. This has occurred proportionally to the worldwide expanding use of ePTFE for mitral valve reconstruction in the form of neochordae to replace ruptured or elongated native chordae or to reinforce areas of leaflet prolapse as an alternative to resection techniques. The isolated reports have rendered it difficult to understand the genesis of this event, and we are awaiting additional analysis of the ultrastructure of the damaged material to shed some light on the subject.

In our initial experience, we had used size 4-0 Gore-Tex sutures but subsequently reverted our practice to using 5-0 because of the presumed greater flexibility and smaller volume of the multiple knots required to fix the suture to the leaflets. Other surgeons have also used 5-0, although some have continued to use 4-0.

We had, until now, assumed that the well-known strength of ePTFE was a guaranty of integrity and have used it liberally, for more than 20 years, in several hundreds of cases. Recently, however, we encountered a couple of other cases of ruptured artificial chordae and started to interrogate ourselves about the correctness of this assumption. In contrast to our first thoughts, we have increasing concern that the 5-0 suture might not be strong enough to withstand the systolic tension of the closing mitral valve leaflets. Hence, we have chosen to return to using the 4-0 size and wish to draw the attention of other surgeons to this potential problem.

Although published data have demonstrated that even after 10 years ePTFE chordae are still flexible and pliable, making them indistinguishable from native chordae, ${ }^{7}$ evidence has also shown that with the progression of time, artificial chordae can degenerate, calcify, and, eventually, rupture.

Early and late rupture has now been reported with both sizes of ePTFE suture; hence, other factors could be involved; however, a little more strength certainly will do no harm.

Manuel J. Antunes, PhD

Gonçalo F. Coutinho, MD

Centre of Cardiothoracic Surgery

University Hospital and Medical

School

Coimbra, Portugal

\section{References}

1. Coutinho GF, Carvalho L, Antunes MJ. Acute mitral regurgitation due to ruptured ePTFE neo-chordae. J Heart Valve Dis. 2007;16:278-81.

2. Butany J, Collins MJ, David TE. Ruptured synthetic expanded polytetrafluoroethylene chordae tendinae. Cardiovasc Pathol. 2004;13:182-4.

3. Farivar RS, Shernan SK, Cohn LH. Late rupture of polytetrafluoroethylene neochordae after mitral valve repair. J Thorac Cardiovasc Surg. 2009; 137:504-6

4. Yamashita MH, Skarsgard PL. Intermediate and early rupture of expanded polytetrafluoroethylene neochordae after mitral valve repair. Ann Thorac Surg. 2011;92:341-3.

5. Bortolotti U, Celiento M, Pratali S, Anastasio G, Pucci A. Recurrent mitral regurgitation due to ruptured artificial chordae: case report and review of the literature. J Heart Valve Dis. 2012;21:440-3.

6. Castillo JG, Anyanwu AC, El-Eshmawi A, Gordon RE, Adams DH. Early rupture of an expanded polytetrafluoroethylene neochord after complex mitral valve repair: an electron microscopic analysis. J Thorac Cardiovasc Surg. 2013;145:e29-31.

7. Salvador L, Mirone S, Bianchini R, Regesta T, Patelli F, Minniti G, et al. A 20-year experience with mitral valve repair with artificial chordae in 608 patients. J Thorac Cardiovasc Surg. 2008;135:1280-7.

http://dx.doi.org/10.1016/ j.jtcvs.2014.07.019

\section{EXPANDED LEVEL OF SYMPATHECTOMY AND INCIDENCE OR SEVERITY OF COMPENSATORY HYPERHIDROSIS}

\section{To the Editor:}

We read with keen interest the article by Gunn and colleagues ${ }^{1}$ regarding their opinion on extension of sympathectomy for the treatment of primary hyperhidrosis and occurrence of compensatory hyperhidrosis
$(\mathrm{CH})$. Their retrospective review of an unrandomized series of patients suggested that severe $\mathrm{CH}$ was rare and occurred irrespective of the level or extension of sympathectomy.

From a methodologic point of view, retrospective studies are, undoubtedly, inferior to prospective assessments, and randomized prospective trials are significantly superior to the former. There have been prospective and randomized studies relating greater frequency and discomfort of $\mathrm{CH}$ after more proximal and extended sympathectomy. ${ }^{2-4}$ In these studies, different patients were randomly assigned to undergo bilateral symmetric sympathectomies (eg, a patient was randomly assigned to undergo bilateral T4 sympathectomy, and another patient was randomly assigned to undergo bilateral T3-T4 sympathectomy). For palmar and axillary hyperhidrosis, $\mathrm{CH}$ was reported with lower frequency in less extensive and less proximal sympathectomies.

A study by Katara and coworkers ${ }^{5}$ had a different design, in which all patients underwent operation on one side with an extensive sympathectomy (T2-T3) and on the other with a more limited sympathectomy (T2). The side of extensive sympathectomy was randomly determined (left vs right), but all patients had an extensive sympathectomy on one side and a limited sympathectomy on the other. Their results showed, at best, that after an extensive sympathectomy on one side, most patients would have $\mathrm{CH}$ bilaterally despite a less extensive (T2 only) sympathectomy on the other side.

We believe that extreme caution must be taken if one considers, from a single institutional and retrospective review, that extended sympathectomy does not influence the outcome of $\mathrm{CH}$, when prospective and randomized studies have suggested otherwise. $\mathrm{CH}$, when present, may become a difficult situation to deal with, and extreme caution must be taken to 